\title{
LRP2 Gene
}

National Cancer Institute

\section{Source}

National Cancer Institute. LRP2 Gene. NCI Thesaurus. Code C113299.

This gene plays a role in receptor-mediated endocytosis. 